\title{
ANDRÉS LAGUNA: TRANSLATION AND THE EARLy MODERN IDEA OF EUROPE ${ }^{1}$
}

\author{
JoSÉ MARÍA PÉREZ FERNÁNDEZ \\ ENGLISH DEPARTMENT \\ UNIVERSITY OF GRANADA
}

In 1539 a Spanish visitor witnessed a cockfight in London. He was surprised at the enthusiastic response of the spectators - even more so when among the audience of what he described as a childish and vile form of entertainment there were some very distinguished gentlemen. One of them, a man of raro ingenio (rare wit) in the description of the Spaniard, must have been piqued by the explicit distaste of a stranger and came forward in defence of the show. In addition to the pastime it provided, he claimed, the disinterested courage displayed by these creatures in a mortal engagement could not fail to inspire any captain, or prince, to fight with at least equal valour for their offspring, their religion, or the honour and well-being of their homeland. The visitor was immediately persuaded by the lively eloquence of the Englishman: "Las quales razones tan viuas, adornadas de palabras muy elegantes, luego me conuencieron". The Spaniard in question was the Hellenist and physician Andrés Laguna, and the story appears embedded in one of the commentaries to his Spanish translation of the Dioscorides. His English interlocutor was "Thomas Huuyat, hombre de raro ingenio, el qual hauia sido Embaxador ciertos años en la corte de la Cesarea", i.e. the diplomat and poet Sir Thomas Wyatt. ${ }^{2}$ Laguna had already given an account of the public spectacles he witnessed in England a few years before: in a commentary to the entry on Liberalitas to his 1543 translation of the pseudoAristotelian De virtutibus (Cologne, 1543, p. $81 \mathrm{ff}$.), Laguna used Henry VIII as a modern example of this particular virtue, exemplified by the lavish entertainment the monarch provided. This included the fights of wild animals celebrated on Sundays in London. Laguna also described the pits in detail, and elaborated on the duelli gallorum utilitas ("the utility of these cockfights", p. 83), to wit, ut... ex animaliculis illis, discerent fortes esse et magnanimi ("to learn from those insignificant animals the virtues of fortitude and magnanimity", p. 83). As Laguna would acknowledge several years later in his Dioscorides, his source for this particular interpretation of these fights was Sir Thomas Wyatt. Even more significantly, Laguna also

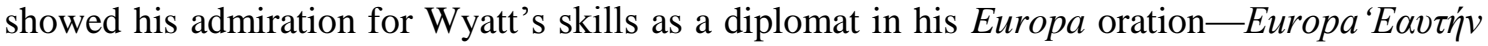
$\tau \imath \mu \omega \rho о \nu \mu \varepsilon ́ v \eta$, hoc est misere se discrucians, suamque calamitatem deplorans (Europa Heautentimoroumene, that is, miserably tormenting itself, and lamenting its calamity) - which he delivered and published in Cologne in 1543. Wyatt, as a diplomat and poet, on the one hand, and Laguna as a physician and scholar, on the other, found common ground in their interest for European affairs and in their activity as translators. The encounter between these two international men of letters and its echoes in Laguna's work illustrate the role played by scholars, diplomats, and translators in the construction of a multilingual idea of Europe stitched together through the textual networks facilitated by printers and publishers.

Between his birth in Segovia (1499) and his death, back in Castile sixty years later (Guadalajara, 1559) Laguna completed a life-cycle that took him all around Europe. After a few

\footnotetext{
${ }^{1}$ This essay is a previous, longer version of an article published in Translation and Literature (vol. 21, 2012). I am grateful to the editors and publishers of Translation and Literature for allowing the publication of this previous version in our institutional repository.

${ }_{2}^{2}$ Pedacio Dioscorides Anazarbeo, Antwerp, Juan Latio, 1555, II.xliii, "De los Gallos y de las Gallinas" (p. 148). All subsequent quotations will refer to this 1555 edition.
} 
years as a student at the university of Salamanca he moved to Paris, where he produced fairly successful critical editions and translations of Aristotelian and pseudo-Aristotelian medical treatises, Gallenic and pseudo-Gallenic texts. Laguna's Parisian production mostly consisted of affordable editions in small formats of rare or previously unavailable texts, such as the Liber de Physiognomicis (1535), De urinis (1536), or the Anatomica methodus seu de sectione humani corporis contemplatio (1535). Galen's works circulated all over sixteenth-century Europe in formats which ranged from the expensive eight folio volumes with his Opera omnia (Venice, 1541-1545) to small pseudo-Gallenic treatises printed in more modest and marketable formats. ${ }^{3}$ The Epitome or summary of Galen's complete works was a particularly popular genre in Renaissance medicine, and there were also popular indexes to aid in the access to the Corpus Gallenicum. This series of Galenic compilations had started with the Speculum Galeni (Lyon, 1512) by the prolific Symphorien Champier - a Lyonese doctor satirised by his fellow physician François Rabelais in Gargantua and Pantagruel. Rabelais himself also engaged in the production of Gallenic materials (Durling, 1961, pp. 243-44). Laguna followed Champier's example with his 5-volume Epitomes omnium Galeni Pergami operum (Venice, 1548), which responded to this double demand: it was a summary with an index and substantial commentaries-his Annotationes in Galeni interpretes. Laguna also shared with his fellow humanist physicians the pride in the proper Latin used in the critical translations of these previously unavailable or very rare texts - of his De phisiognomicis Laguna claimed that it was in feliciorem latinitatem restitutus - now released for the thriving market of medical handbooks. From an early stage in his career Laguna also came to exemplify the intersection of science and literature with the book market. One of his Aristotelian translations shared the same volume with Latin renderings of two Lucianic dialogues of medical interest, Tragopodagra and Ocypus (Aristotelis de mundo seu de cosmographia liber unus ad Alexandrum. Luciani dialogus Tragopodagra nominatus. Tragoedia alia Luciani Ocypus dicta, Alcalá de Henares, 1538). His medical education in Salamanca and Paris had turned him into a philologist, editor and translator - whose own compilations were frequently reprinted, and also translated. His De mundo went through another edition in Cologne coinciding with Laguna's productive stay in that city in 1543-about which more below. Tragopodagra would be reprinted in Rome in 1551, together with Ocypus, under the title De articulari morbo commentarius. The following year it was translated into Italian. John Jones rendered into English part of Laguna's Epitomes omnium Galeni Pergameni operum as Galens books of Elements as they be in the Epitome (London, 1574, STC (2nd ed.) 11537.3).

During the last few decades, several scholars have addressed Laguna's Gallenic production. In 1955 Cesar E. Dubler's Don Andrés de Laguna y su época provided an account of Laguna's career, which includes a detailed survey of primary documents, and a chronological list of Laguna's publications (Barcelona: Emporium, 1955, volume 4 of his La Materia Médica de Dioscórides. Transmisión medieval y renacentista, published in six volumes between 1953 and 1959). Three years later Teófilo Hernando published his Vida y labor médica del doctor Andrés Laguna (Segovia: Instituto Diego de Colmenares, 1958), and in 1968 Hernando also edited a facsimile of the 1555 Dioscorides with an introductory essay (Madrid: Instituto de España, 2 vols). In 2000 Miguel Ángel González Manjarrés approached Laguna's scientific achievements from a philological perspective in his Andrés Laguna y el humanismo médico: estudio filológico (Valladolid: Junta de Castilla y León \& Caja Duero). More recent accounts include Juan Riera Palmero ("Andrés Laguna y el galenismo renacentista"), which is part of a fine volume that approaches Laguna from a fresh interdisciplinary perspective (J.L. García Hourcade y J.M. Moreno Yuste, editors. Andrés Laguna. Humanismo, ciencia y política en la Europa renacentista, Valladolid: Junta de Castilla y León, 2001; Riera Palmero's chapter is in pp. 161177). This article takes as its starting point the data and insights provided by this substantial body of scholarship to shed some new light on Laguna as an inherently European scholar. Although recent interdisciplinary accounts have already started to yield interesting insights, the

\footnotetext{
${ }^{3}$ For Galen in the Renaissance, see Richard J. Durling's "A chronological census of Renaissance editions and translations of Galen”, Journal of the Warburg and Courtauld Institutes, vol. 24(3/4), 1961, pp. 230-305.
} 
intersection between Laguna's activities as a translator, on the one hand, and the interface between the languages of literature and science in his texts, on the other, constitute essential aspects that have not been explored yet.

Laguna was certainly an early modern European citizen if we understand Europe as a transnational constellation of scholarly and scientific communities. ${ }^{4} \mathrm{He}$ belonged in that group of humanists, diplomats, and expatriates who crisscrossed the continent in search of promotion, intellectual patronage or refuge, as they also corresponded with each other and sought publishers to produce and distribute not just their original works, but also their editions, translations and commentaries. The first part of my essay will approach Laguna as a case study to illustrate some of the manifold relations that linked these individuals, and the role that they played in the establishment of an early modern idea of Europe. Laguna's intellectual production, and in particular his philological abilities put at the service of scientific and literary translation, were of a piece with an early drift towards encyclopedism, and with moves not just for the establishment of an irenic via media in things theological and political, but also with the advocacy of a middling style in the vernaculars that frequently resorted to common narrative techniques for the distribution of scientific knowledge. The final section of this article will show how this incipient encyclopedism would eventually lead to the creation of a mixed prose style whose features overlapped with the discursive strategies used by certain varieties of popular prose fiction - a genre with which these compilators shared a considerable portion of the reading markets.

Back in Spain from Paris around late 1535 or early 1536, Laguna continued with his series of editions and translations. He also joined the Imperial court in Toledo under the patronage of one of the Emperor's physicians, Francisco López de Villalobos-who shared with Laguna his Jewish converso background and an interest in translation. After the death of Empress Isabel on May $1^{\text {st }} 1539$ Villalobos arguably lost the favour of the court, and the disgrace of his mentor must have led Laguna to England around the summer of the same year. Consequently Laguna must have met Wyatt in London ca. June - Nov. 1539, after the English diplomat had just arrived from a long mission in Spain. One of Wyatt's tasks during this embassy had been to avoid an impending truce between Francis I and Charles V that would leave Henry VIII isolated in the European scene. Wyatt's reaction to Laguna's comments, as recounted in the Dioscorides, and the English diplomat's emphasis on the need to defend the honour of the homeland, its religion and temples, in the face of a negative opinion voiced by a subject of the Emperor, would not have been out of place in the paranoid atmosphere created by the fear of an invasion during these months in England. Soon after this meeting with Laguna, Wyatt was sent again to the Emperor late in November of $1539 .{ }^{5}$ Charles V was at the time on his way to Ghent from Spain after a diplomatically successful visit to Francis I in Paris. The Emperor arrived with 5000 German mercenaries to crush a civic rebellion in his hometown. Between 1537 and his death in 1542 Wyatt was constantly on the move, striving to readjust the balance of power between Charles and Francis into a more advantageous position for his country. And in spite of the fact that this second mission was not particularly successful for Wyatt, Laguna was certainly impressed by his eloquence when he personally met him in London in 1539, and by his overall diplomatic skills. The political, religious and military events that surrounded Wyatt's embassy

\footnotetext{
${ }^{4}$ See Anthony Grafton's Worlds Made by Words: Scholarship and Community in the Modern West (Cambridge, Mass. \& London: Harvard University Press, 2009), in particular chapter one ("A Sketch Map of a Lost Continent: The Republic of Letters", pp. 9-34). ${ }^{5}$ For more details on Wyatt's activities as a diplomat, see chapters III-V of Kenneth Muir's Life and letters of Sir Thomas Wyatt (Liverpool University Press, 1963). On the historical background for these years see Scarisbrick, Henry VIII, New Haven \& London: Yale U.P., 1997, pp. 361-3.
} 
contribute to an understanding of Laguna's 1543 Europa oration, in which the Spanish physician praised the English Petrarchist as one of the diplomats who had taken considerable risks to set "in good order the affairs of Europe". 6

Towards the end of 1539 or early 1540, Laguna rushed to the Netherlands in search of patronage at the Imperial court. He eventually obtained an appointment as city doctor in Metz between 1540 and 1545 - with a brief but extremely fruitful interlude spent in Cologne. His new situation linked him with the physician François Rabelais, who would take up Laguna's position when he left in 1545. While in Ghent Laguna must have witnessed Charles' exemplarily harsh repression of the rebels, and later in Metz he had the opportunity to experience different aspects of the European political, military and doctrinal strife as it reflected in the microcosm of this city. 1538 had marked the onset of a brief peaceful interlude in the constant competition between Charles V and Francis I. Their enmity had frequently put Henry VIII in the advantageous position of power-broker, and his diplomacy made skillful use of this situation. This historical background throws some significant light upon Laguna's comment on the features of English fighting-cocks, which are described as bold animals who even dare confront the eagle face to face. These animals also appear as the sort of peace-brokers that side with the weaker party when peace negotiations fail. Laguna was first made aware of these virtues, he admits, during his 1539 visit to London:

Es el Gallo vn animal ambitioso, feroz, soberuio, y en tanto grado animoso, que con el Aguila rostro à rostro se atreue muchas vezes à pelear. De mas d'esto, es muy amigo de despartir, sin querer ser jamas despartido: y quando vee alguna vez otros dos contrastando, se mete en medio, y no pudiendo reconciliarlos, fauorece siempre a la parte mas flaca. Conoci la gran virtud y valor de los Gallos, el año de 39. en Londres de Ingalaterra: adonde el Rey Henrrique Octauo de aqueste nombre, tenia con grande artificio fabricado vn amphitheatro muy sumptuoso, à manera de coliseo, destinado solamente para las peleas y luchas de aquestos animalejos: en el torno y cerca del qual hauia innumeras caponeras, pertenecientes à muchos Principes y Varones del Reyno. (Laguna, Dioscorides, p. 147)

But May 1538 was not the right time for the peace-making skills of the English gallus: it would take Pope Paul III's diplomacy to strike a deal in Nice between the envoys of Charles V and Francis I. This peace was later ratified in person during a summit between the two monarchs in Aigues-Mortes, which resulted in the signing of a ten-year truce. Wyatt had witnessed all these negotiations, since he was also present in Nice as part of the Imperial entourage. A few months before Aigues-Mortes (February 1538) Rome, Venice, Charles V and his brother Ferdinand of Habsburg had also agreed to create the Holy League against the Turks. At this point Charles V even toyed with the idea of launching an assault upon Constantinople. All these moves stirred enthusiasm among many at the prospect that Christian Europe would finally come together under the leadership of the Emperor, first to fight the infidels, and then to heal the internal rift between Roman Catholicism and Lutheranism. ${ }^{8}$ These hopes, however, would soon be dashed. On the theological front, Charles failed in his attempt to persuade orthodox Catholics into a doctrinal agreement with the Lutherans at the Diet of Ratisbon in 1541. On the military front, 1541 also saw another Turkish onslaught upon Eastern Europe, and to the South the Imperial

\footnotetext{
${ }^{6}$ The most recent edition of the oration has been prepared and translated by M.A. González Manjarrés, with an introduction by Joseph Pérez (Valladolid: Junta de Castilla y León, 2001). For Laguna's passage on Wyatt, see pp. 174-5. All subsequent quotations will refer to this edition.

${ }^{7}$ The cock is an ambitious, ferocious, and proud animal, and in such degree corageous that it frequently dares confront the Eagle face to face. Besides this, it is also inclined to mediate, without ever admitting mediation for itself. And when it sees two parties in conflict, it does intervene, and if unable to reconcile them, will always side with the weakest party. I became familiar with the great virtue and valour of Cocks in the year of 39, in London of England, where King Henry VIII had with great artifice built a very sumptuous amphitheatre, by way of a coliseum, meant only for the fights and combats between these animals: and in the vicinity of this pit there were innumerable coops, which belonged to many Princes and Noble Men of this kingdom. Unless otherwise indicated, all translations are mine.

${ }^{8}$ For an account of the political background, see Manuel Fernández Álvarez, Carlos V. El César y el hombre. Madrid: Espasa-Calpe \& Fundación Academia Europea de Yuste, 1999, pp. 557-587.
} 
failure in Algiers. To deal the final blow to this peaceful lull in 1542 Francis I ended the truce achieved after the negotiations of Nice and Aigues-Mortes just a few years before.

Against this background Laguna delivered his Europa oration in 1543, at the Faculty of Arts in the University of Cologne. The funerary setting was provided by a hall dramatically decorated with torches and black arras hanging from its walls. The oration was couched as the disconsolate lament of Europe allegorized as a widow embattled by her own children. She only found consolation in those who during the past few years had sought to succor her. Only Emperor Charles among her children, Europa claimed in her plaint (pp. 156-7), had come to her defence, with assistance from his allies Ferdinand King of Hungary, Pope Paul III, the kings of Portugal and England, the Archbishops of Treveris and Cologne, the Cardinal of Maguntia, or the Dukes of Bavaria. Francis I and the Venetian Republic are absent from this account: in both cases they had recently either reached alliances with the Turkish Empire or avoided direct confrontation with it. Laguna's recent editor, M.A. González Manjarrés ("Introducción", 2001, pp. 80, 86-87), provides an account of Laguna's self-interested partisanship, under whose light the oration appears as little else than a piece of rhetorical sophistry and ideological imposture at the service of the Catholic policies of Charles V and his allies. Before González Manjarrés, Marcel Bataillon had already suggested that the Europa oration was a self-serving exercise with which Laguna was trying to obtain the favor of the Emperor and the other potentates who are depicted as the only friends and defenders of Europe in this moment of turmoil. In contrast with these interpretations, Joseph Pérez has offered a more benevolent reading of Laguna. ${ }^{9}$

Whatever the case, the list of defenders of Europe that feature in Laguna's oration reads not just as a Who's Who of the Imperial party in 1543, but also as a directory of Europe's top humanist diplomats at the court of Charles V-Wyatt among them. Significantly Laguna's roll includes both Protestants and Catholics among Europe's benefactors. One of them was Nicolas Perrenot de Granvelle, who had become Imperial chancellor after Gattinara's death in 1530, played a fundamental role in the 1538 Nice talks, and also strove to reach an agreement between German Protestants and Catholics in $1540 .{ }^{10}$ Wyatt also appears in the company of Louis of Praet. A generous patron to many scholars, Praet was appointed Imperial ambassador to England between 1522 and 1525-where he coincided with Juan Luis Vives, another important European pacifist who dedicated some of his works to Praet. Gabriel de Grammont, the French Bishop of Tarbes also featured among the benefactors of Europe. Described by Bietenholz as "one of Francis I's most able diplomats" (2003, vol. 2, p. 122) Grammont had negotiated a peace treaty between France and Spain a few years before, and was sent on several missions to England and the Imperial court. Another member of this team of Europhile diplomats was Cornelius de Schepper, whose missions included embassies to Constantinople in 1533 and 1534. Schepper was a friend and correspondent of Erasmus, and one of his most enthusiastic defenders at the court of Charles V against the attacks of conservative theologians (Bietenholz, 2003, vol. 3, pp. 218-20). He also corresponded with the Spanish Erasmian Alfonso de Valdés - secretary of Latin letters to the Emperor. Laguna's list is much longer and it will deserve a separate essay of its own, but even a brief account of close connections with others not listed by Laguna provides a revealing profile of this European network of humanists and diplomats. ${ }^{11}$

Juan Luis Vives (1493 - 1540) was educated in his native Valencia and left Spain for good in his teens. He moved to the University of Paris first, and ended up settling in the Low Countries, with occasional periods spent in England - where he became a protegé of Cardinal Wolsey and Catherine of Aragon. Another less known travelling humanist who deserves some special

\footnotetext{
${ }^{9}$ Joseph Pérez, "Una visión humanista de Europa a mediados del siglo XVI: el Discurso sobre Europa del Doctor Laguna", in García Hourcade \& Moreno Yuste, pp. 51-58. See also Bataillon's “Sur l'humanisme du Docteur Laguna: Deux petits livres latins de 1543", Romance Philology, 17:2 (1963), pp. 207-234.

${ }^{10}$ Rosemarie Aulinger, "Nicolas Perrenot de Granvelle" in P.G. Bietenholz, ed. Contemporaries of Erasmus. A Biographical Register of the Renaissance and Reformation. Toronto, Buffalo \& London: U. of Toronto Press, 2003, vol. 3, pp. 68-70.

${ }^{11}$ For more details, and the full list of Europe's friends, see González Manjarrés, 2001, pp. 166-75, and his notes.
} 
attention was Pedro Juan Olivar. Olivar studied at the universities of Alcalá and Paris, after which he moved to Flanders and became part of the humanist circles of Vives and Cranevelt. Between 1522 and 1525 he moved with Vives to the English court, where both coincided with the Imperial ambassador Louis of Praet. Upon his return to Spain in 1525 he was banned from teaching in Valencia by the anti-Erasmian Juan de Celaya. He left Spain again around 1535 to teach at the universities of Poitiers and Paris. In 1542 the renovated conflict between France and Spain led him back to England, where he became the protegé of Stephen Gardiner-whom he had met in Paris when Gardiner was the English ambassador there between 1535 and 1538. While in England he taught at Oxford between 1542-43, put his pen at the service of Henry VIII's caesaropapist policy, and compiled a series of manuscript textbooks for the education of Prince Edward. Olivar's Catholicism eventually drove him away from England and in 1553 we find him in Cologne, where he published a defence of the Real Presence. ${ }^{12}$ Like Laguna and Vives, Olivar constitutes an excellent example of a European wandering humanist. He was from Valencia like Vives, and like Vives he felt stifled by the anti-humanist atmosphere in this city during the early decades of the 16th century. As a Catholic eventually forced to leave Protestant England he is also a counter-example for other fellow humanists, translators and theologians, like Francisco de Enzinas, or Antonio del Corro, whose Protestantism sent them away from Spain into permanent European exile-del Corro would end up in Elizabethan Oxford, and Enzinas also spent some time in Cambridge. Alfonso de Valdés, whose Erasmian sympathies kept him away from Spain, also illustrates the role played by this group of scholars, diplomats and courtiers in their search for a common European via media. ${ }^{13}$

The intellectual mileu that facilitated the emergence of Vives, Olivar, Laguna, or Valdés was made possible by the late $15^{\text {th }}$-century patronage of the Castilian and Aragonese courts first, and then by the cultural policies of the Catholic Monarchs. This drift survived into the early years of the sixteenth century: when in 1517 Charles V arrived in his new Hispanic kingdoms he brought with him an Erasmian upbringing and a team of counsellors educated in the same tradition. But after 1523 these Erasmian counsellors would gradually lose influence in favour of the more orthodox entourage that Charles had inherited from the Aragonese court of his grandfather Ferdinand. A few years later the Erasmians in Spain had been confined to the circle of the Empress, where they managed to maintain some influence on the education of the young heir, the future Philip II. Alfonso de Valdés himself elaborated a draft for his educational programme. Bernabé del Busto translated for him Erasmus's Institutio principis christiani in 1530 - a book originally composed for the education of the young Charles of Habsburg. In 1543 Gonzalo Pérez, a disciple and protegé of Alfonso de Valdés, was appointed secretary to Prince Philip. The dedicatee of some of Laguna's publications, Gonzalo Pérez also penned the Ulyxea, the first direct translation of Homer into Spanish. ${ }^{14}$ Laguna had been long acquainted with Gonzalo Pérez, who was a fellow Hellenist and also a Segovian. His first dedication dates from 1538 (Ocypus, see above), and 16 years later Laguna dedicated him his Annotationes in Dioscoridem (1554). The great Erasmian hopes that these scholars set on Charles's heir found its most clear expression in Calvete de Estrella's Felicísimo viaje (El felicissimo viaje del mvy alto y mvy Poderoso Principe Don Phelippe, Antwerp, 1552), an official chronicle of prince Philip's 1548 European tour throughout all the different realms that he was about to inherit from his father. When Philip's entourage returned to Flanders in 1555, they reacquainted themselves with the Erasmian circles that they had visited seven years before during this Felicísimo viaje. But by 1555 the religious and political landscape had changed and Philip was about to embark in his anti-Protestant crackdown. Crowned in 1556, Philip II was soon made aware of the wave of

\footnotetext{
${ }^{12}$ See M. Almenara Sebastiá, "P.J. Olivar, cortesano e historiador de Enrique VIII", in J. Pérez i Durá \& J.M. Estellés, eds. Los humanistas valencianos y sus relaciones con Europa: de Vives a Mayans. Valencia: Ayuntamiento, 1998 , pp. 37-56.

${ }^{13}$ On Enzinas, see J. Bergua Cavero's Francisco de Enzinas: Un humanista reformado en la Europa de Carlos V (Madrid: Trotta, 2006). On Antonio del Corro see P.J. Hauben, Three Spanish Heretics and the Reformation: Antonio del Corro, Cassiodoro de Reina, Cypriano de Valera (Geneve: Droz, 1967).

${ }^{14}$ See Dubler, 1955, p. 62. Gonzalo Pérez's partial version of books I-XIII was printed in Salamanca by Portonaris in 1550, and in the same year in Antwerp by Steelsius. The first complete translation appeared in 1556, also in Antwerp with a dedication to Philip II. The definitive version appeared in Venice in 1562. For recent work on the impact of, inter alia, Perez's translation, see Christopher D. Johnson's “"El Homero español': Translation and Shipwreck”, Translation and Literature 20(2011): 157-74.
} 
Protestantism that was penetrating the Netherlands, the continuous trade of heretic books from Germany, and of the connections between these phenomena and the Lutherans that had been exposed around 1557-58 in Valladolid and Seville-Antonio del Corro among them. The events of these years determined Philip II's future religious policy, and the monarch in person presided over one of the autos de fe celebrated in Valladolid in 1559- the year Andrés Laguna died.

Laguna belongs in that group of humanists who had sought to mediate between the orthodox and the reformist factions in Europe before the breakup between these two worldviews started to tear the continent apart in the long series of wars that would cease only almost a century later with the Peace of Westphalia. Unlike some of his fellow travellers, Laguna managed to negotiate the boundaries between exile and conformity, and could eventually return to die in his homeland. But his European wanderings gave him the opportunity to engage with both sides of these controversies, and even to take an active interest in the Turk - that political, cultural and religious other that was contributing to the creation of an early modern idea of Europe. Laguna's De origine regum Turcarum was a Latin translation of an Italian treatise on the Turks, which he took up at the behest of the rector of the University of Cologne, Adolph von Eichholtz, and which Laguna dedicated to the Dean of Cologne Cathedral, Henrich von Stolberg. This translation was originally published in Cologne by Ruremundanus in 1543, and went through two subsequent editions in Antwerp (1554) and Maguntia in 1552 (see C.E. Dubler 1955, p. 114). Under the patronage of von Eichholtz Laguna also published a short medical treatise on the plague (Strassbourg 1542), and pronounced his Europa oration. He also printed a Latin translation of the pseudo-Galenic De philosophica historia, and two pseudo-Aristotelian works, De natura stirpium and the aforementioned De virtitubus. In these works he combined his professional interest in early modern science with an Erasmian emphasis on moral philosophy and social critique - all of which can be found in the abundant scholia to his translation of De virtutibus. He dedicated his Europa oration to Archbishop Hermann von Wied-a Catholic who at the time tolerated the preaching activities of Melanchthon and Bucer in Cologne, and eventually converted to Protestantism in 1547. In the oration Wied is also listed by Europe as meus fautor praecipuus, "my main benefactor" (p. 168). In the same passage Laguna also included the Archbishop of Trier, Johann Ludwig von Hagen, as one of Europe's defenders. Von Hagen was an orthodox Catholic who employed one of the most prominent heretic-hunters in Europe, Jacob Latomus, as his private secretary. The translations of the Psalms quoted by Laguna in his Europa were taken from the recent Latin version of Campensis, which was subsequently banned by the Inquisition. Proof of Laguna's prudence is that in the printed version of the oration he included an appendix in which he recanted his use of Campensis' Psalms, and proclaimed that Jerome's Vulgate version was much better (pp. 192-3). He also maintained a deliberate silence about his Europa oration during the last years of his life-all of which must have facilitated a safe return to Spain around 1558. But in 1543 Laguna's conciliatory approach stemmed from the public controversies that he witnessed in Cologne, where the archbishop sympathised with the Reformers while the political authorities, the university and part of the local Church sided with those who refused to reach any type of compromise with the Protestants. Cologne was during these years a microcosm of the European public sphere. Its university was a bastion of Imperial policy and one of its ideological powerhouses. Its leader, and Laguna's patron, Adolph von Eichholtz was always close to Erasmian pacifism. Other irenic tendencies in Cologne were represented by the attitudes of certain religious orders that defended the reconciliation between Catholics and Protestants, such as the Carmelites led by Kasper Dorler and Eberhard Billick. If in the long run Laguna's selfserving caution is undeniable, his 1543 paficism is patent too.

Europa heautentimoroumene belongs in an irenic tradition established by some important precedents. One of them was Erasmus's Querela pacis (Basel, 1517), composed soon after he became Charles of Habsburg's counselor. Erasmus had long been a proponent of pacifism: some of his earliest statements in this direction included his Panegyricus of 1504, followed by passages of his Institutio principis christiani-which had been composed in 1515 for the education of young Charles of Habsburg. Alongside echoes of these two founding texts, 
Bataillon (1963, p. 211) also found in Laguna traces of Erasmus's Adagia, in particular the section Dulce bellum inexpertis (Adag. IV.i.1, col. 1067 s.). Juan Luis Vives's De Europae dissidiis (Bruges, 1526) followed in the wake of Erasmus, and of the events that led to the Universal Peace of 1518, which was signed by England and France, and was ratified by other European powers as well as a host of minor players. With its unprecedented geopolitical range this treaty was a watershed in early modern European diplomacy, and it was regarded by Vives and many others as an excellent opportunity to come up with a united front to fulfill the ideals of peace, justice and harmony among Christian princes as they also confronted the Turkish threat. Vives's essay was in reality a combination of new and previously published texts which appeared in a single volume with the general title of De Europae dissidiis et re publica. It contained - inter alia - appeals for peace in the form of a letter to the new Pope Hadrian VI (De Europae statu ac tumultibus, originally dated and printed at Louvain in 1522). A few years later, Vives dedicated his De concordia et discordia in humano genere (1529) to Charles V. This volume was followed by De pacificatione a few months later - this time dedicated to Alonso de Manrique, the Spanish Erasmian who succeeded Hadrian of Utrecht as Charles V's Inquisitor General after the latter became Pope Hadrian VI in 1522.

Europa Heautentimoroumene also belongs in a genealogy of texts that extended well beyond the date of Laguna's oration. In parallel with humanist pacifism and in response to the growing religious divide in the continent these volumes gradually wove a certain idea of tolerance, expressed through a dispassionate approach to doctrinal strife and the defence of universal values that prefigure the ideals of Enlightened Europe. On the threshold of the long series of European Wars of Religion that would ravage the continent for decades, Laguna follows Erasmus and Vives as he also precedes others in their defence of tolerance and a via media to mend the fragmentation of Europe. In Laguna and some of his contemporaries Europe starts to rise out of the ruins of the ideal Christian Universal Monarchy-the Universitas Christiana so strenuously, but most unsuccessfully, pursued by Charles $\mathrm{V}$-as a secularized multilingual cultural unity anchored upon the classical Roman and Greek tradition. Significantly, Laguna construes the transnational audience that he aspires to address with his oration as viri citra controversiam doctissimi - learned men devoid of all controversy. In other words, a group of adiaphoric intellectuals, members of a European elite that could take upon their shoulders the task of reconstituting the lost unity upon refurbished principles. Europe becomes a cultural community brought together by certain shared Christian elements, the treasures of Classical Antiquity, and the multilingual network of texts and translations that circulated thanks to the printers and publishers, the diplomats and expatriate humanists, who criscrossed the continent during these decades. Joseph Pérez (2001) has demonstrated how these irenic and proto-tolerant tendencies appeared in Europe in diverse contexts and were formulated in a variety of tones. This list includes François Baudoin (1520-1573), who shared with Laguna the idea that Europe should come together under the leadership of Charles V to oppose the Turkish threat; Louis Le Roy's Oratio de pace et concordia (1559), published after the Peace of Cateau-Cambrésis; or Guillaume Postel's De orbis terrae Concordia (Basel, 1544), which proposed a Christian-based Universalist religion that would integrate Judaism and Islam.

Translation and diplomacy intersect with this early modern idea of Europe and its accompanying pacifism. We have already sampled some of the individuals singled out by Laguna as friends of Europe, and a necessarily brief section of their manifold external connections. This second list could be enlarged with a couple of English scholars from two different generations. Thomas Paynell (d. 1564?) translated Erasmus's De contemptu mundi into English in 1533, and his rendering of the Querela pacis was printed in London in 1559. Like Laguna, Paynell was a doctor who translated and penned several books on a variety of topics, from medical matters to the counsel of magistrates. In 1553 he produced a translation of Vives's De officio mariti (The Office and Duetie of an Husband). He also served as a diplomat: it appears that Cromwell sent him with Christopher Mount on a mission to the Protestant Princes of Germany. A member of Thomas More's circle - for whose works he elaborated an index under Mary Tudor-Paynell remained a Catholic and managed to survive into Elizabeth's reign. 
His commonplace book features Paynell's English translations from Luther's Latin commentaries on the Psalms side by side with original lines in honour of Thomas More. ${ }^{15}$ Paynell was followed in this ecumenical and irenic drift by Sir Edwin Sandys (1561-1629), the English politician and diplomat who toured Protestant and Catholic Europe between 1596 and 1599. Upon his return he composed a balanced report on the diversified religious situation of the continent, which he titled A Relation of the State of Religion (London, 1605). It went through fourteen editions over the course of the $17^{\text {th }}$ century, and was also translated into Italian, French and Dutch. It counted Paolo Sarpi and Hugo Grotius among its readers.

This tolerant view of Europe was shaped by the joint pressures of its internal religious division and the external threat of the Turkish Empire. Aeneas Sylvius Piccolomini had already described Europe as "our home" in a 1458 text that dealt with the Turkish conquest of Constantinople. ${ }^{16}$ In spite of the fact that this led to an essentially Christian view of European identity, the increasing awareness of a Muslim other also induced many to question the universalist aspirations of an exclusively Christian world-view. This new attitude appears in a multitude of works, one of which - of still uncertain authorship - was at one point attributed to Laguna. The Erasmian tone of El Viaje de Turquía (1557) follows humanist pacifism in its advocacy of Christian unity to confront the Turkish infidels, but at the same time it also redefines European unity in terms that fail to appeal to an explicit notion of Christian crusade. The Turkish danger appears as an actual threat to the freedom, peace and security of the European nations rather than a fundamentally doctrinal problem. On the other hand, and in spite of the fact that the Turks are described as savage and cruel, their culture is also praised for its religious tolerance. One of the speakers in the dialogue declares that it matters little to the Turkish Emperor whether his subjects are Jewish, Christian or Muslim, as long as they dutifully pay their taxes. ${ }^{17}$ What really distinguishes the Turks from the Christian monarchs here is the fact that the former display political despotism, whereas in Europe the rule of law provides security, establishes the obligations, and protects the rights of individuals. Machiavelli had already traced the dividing lines between the civilized West and the barbaric other along the lines of the despotic regimes that treat their subjects as slaves. In contrast with the latter there are those regimes where the ancient aristocracy counterbalances the power of the monarch and thus avoids a drift towards absolutism. In the Cohortatio ad Carolum V-Juan Ginés de Sepúlveda's address to Charles V upon his arrival in Bologne to be crowned as Emperor in 1530 - the paradigmatic European state had already been defined as a republic of free men. A similar contrast between English due process of law and the arbitrary despotism of infidels also featured a few decades later in Shakespeare's Richard III (III.v.40-45). A couple of centuries later Voltaire and Montesquieu would voice similar opinions again. ${ }^{18}$

In the same passage Machiavelli also formulated his idea of Europe as a multiplicity of states in search of a precarious balance beyond the idea of empire. The mosaic of linguistic communities and the texts that embody them were the fragments that mapped this political vision, and the complexity of this network was compounded by liminal regions where several languages were spoken. ${ }^{19}$ Europe appears as a transnational web with a constellation of centers held together as

\footnotetext{
${ }^{15}$ For more details on Paynell, see J.K. McConica, English Humanists and Reformation Politics under Henry VIII and Edward VI. Oxford: Clarendon Press, 1965, pp. 138-140. See also Geoffrey Eatough's entry on Paynell in the DNB.

16 "Nunc vero in Europa, id est, in patria, in domo propria, in sede nostra, percussi caesique sumus" (De Constantinopolitana clade ac bello contra Turcos congregando), quoted by Denis de Rougemont, Tres milenios de Europa. La conciencia europea a través de los textos. Translated by Fernando Vela, Madrid: Revista de Occidente, 1963, p. 80.

${ }^{17}$ Viaje de Turquía, ed. F. García Salinero, Madrid: Cátedra, 2000, p. 253. See also Pérez, 2001, "Prólogo", in González Manjarrés ed., pp. 20-23.

${ }_{18}$ Machiavelli, The Prince, ed. Q. Skinner \& R, Prince, C.U.P., 1988, ch. IV, p. 15. Voltaire, The Age of Louis XIV, Chap. II, "The States of Europe before Louis XIV", translated by R. Griffith, vol. I, London: Fielding and Walker, 1779, p. 8. See Anthony Pagden. "Europe: Conceptualizing a Continent", in Anthony Pagden, ed. The Idea of Europe. From Antiquity to the European Union. Washington, D.C. \& Cambridge, UK: Woodrow Wilson Center Press \& C.U.P., 2002, pp. 27-8, 33-54. This interpretation of Machiavelli and the critical narrative it sustains is disputed by Lucette Valensi in "The Making of a Political Paradigm: The Ottoman State and Oriental Despotism" (in A. Grafton \& A. Blair, eds. The Transmission of Culture in Early Modern Europe, Philadelphia: U. of Pennsylvania Press, 1990, pp. 173-203), in particular pp. 194-200.

${ }^{19}$ For a useful survey of Early Modern awareness of linguistic diversity, and the theoretical production of the period on this topic, see Peter Burke, "Linguistic diversity" (in Languages and Communities in Early Modern Europe, C.U.P., 2004, pp. 25-42, also 63-
} 
much by the tensions that differentiated them as by the elements they shared. Translation and the book trade were among its most important cohesive and tensing agents: through the material networks of print and the virtual processes of interlinguistic exchange that they sustained there circulated a colourful array of discursive standards and values that turned early modern Europe into a variegated but dynamically coherent mosaic informed by a multiplicity of spheres. These spheres in turn consisted of reading communities that to a large extent resulted from the new cultural and material conditions facilitated by the invention of print, and they also entered into a complex relation with the book market through the creation of demands that drove the production of printed volumes in new directions. The final section of this article will return to Laguna to illustrate the emergence of a middle prose style that exemplifies the drift towards intra- and interlinguistic standardization among these different spheres.

\section{III}

One of the most successful vehicles for the articulation of the European networks of printed matter and their processes of exchange was a type of prose style that could appeal to a large readership and thus respond to the widest possible demand in order to maximize profits, as it also facilitated the communication between different spheres of specialized knowledge. Translation, understood in its literal sense as the transfer of meanings between different linguistic systems, and also in its metaphorical dimension as the carrying over of knowledge between different realms - even within the same linguistic community-also played a central role. The tension between Latin as the language of international scholarship, the depository of the cultural and political capital of Ancient Rome, on the one hand, and the emerging vernaculars that competed with each other for supremacy as they also tried to appropriate the prestige of Latin, on the other, was instrumental in this process.

In the late fifteenth century, and following the lead of Lorenzo Valla's Elegantiae linguae Latinae, Elio Antonio de Nebrija began to establish proper usage of the vernacular with his Gramática de la Lengua Castellana (1492). Nebrija's Gramática is a translatio into Spanish of the linguistic and stylistic standards postulated for Latin by Valla. In 1549 Du Bellay published La Deffence, et Illustration de la Langue Francoyse, whose declared intention was to prove that French could display the same level of excellence achieved by other languages. This capacity was ratified by the numerous books "... traduits en français par maintes excellentes plumes de notre temps" ${ }^{20}$ Du Bellay defines elocution as a virtue that consists of "mots propres, usités, et non aliénés du commun usage de parler..." (ibid. p. 233). For du Bellay, however, translation is only a first step that can never capture that "je ne sais quoi" (sic) inherent to each language. But du Bellay is here talking about the translation of poetry, a tall order indeed: not even Homer or Virgil, he claims, could have captured the poetic grace of Petrarch's "vulgaire toscan" in their native Greek and Latin. However, if translation is unable to give the target language the final aesthetic shine that can only come from its natural je ne sais quoi, it does serve a more down-toearth purpose, since it is "fort utile pour instruire les ignorants des langues étrangères en la connaissance des choses". ${ }^{21}$ In England the dedicatory preface of Palsgrave's Ecphrasis Anglica

\footnotetext{
74). See also John Hale's "Borders and Languages", in his The Civilization of Europe in the Renaissance (London: HarperCollins, 1993), pp. 143-63. Needless to say, this linguistic diversity and the role it played in the idea of Europe, was not a new phenomenon: on this, and on the role played by translators and interpreters in those regions that were linguistically mixed, see "Race Relations on the Frontiers of Latin Europe (1): Language and Law", chapter 8 in Robert Bartlett's The Making of Europe: Conquest, Colonization and Cultural Change, 950-1350 (London: Penguin, 1994) pp. 197-220. For a survey of the political counterpart to this cultural and linguistic diversity see Maravall's "Universalismo a través de pluralidad" (chapter IV in his Carlos V y el pensamiento politico del Renacimiento, 1999, pp. 179-208).

${ }^{20}$ Joachim du Bellay. Les Regrets. Les Antiquités de Rome. Défence et Illustration de la Langue française. Preface de J. Borel, ed. S. de Sacy. Paris: Gallimard, 1967, p. 231, I.iv, "Que la langue française n'est si pauvre que beaucoup l'estiment"

${ }^{21}$ Ibid. I.v. "Que les traductions ne sont suffisantes pour donner perfection à la langue française”, p. 234.
} 
in Comoediam Acolasti (1540) also expressed the need to defend and illustrate-i.e. to enlighten, or cleanse and fix - the proper usage of English as common currency. The imitation of Latin style through the translation of Acolastus will fix and homogenize the use of English. As Palsgrave claims in his dedication to Henry VIII: “ ... the speache of your graces subiectes shoulde by that meane haue a great aduauntage to waxe vniforme, throughe out all your graces dominions". 22 These are all strategies to normalize linguistic usage with a view to the creation of a relatively stable linguistic community and a comprehensive sphere of readers.

These strategies resulted in texts targeted for a wider readership made up of common, averageeducated speakers, among whom knowledge could circulate using the circuits of authors, translators, printers and booksellers. John Dolman's preface to his English translation of Cicero's Tusculan Disputations (London, 1561) justifies his use of plain English to make the doctrines of the Roman rhetorician available beyond academic reading communities. ${ }^{23}$ Laguna himself engaged in this sort of strategy with his translation of Cicero's Catilinariae (Quatro elegantissimas y grauissimas orationes de M.T. Ciceron, contra Catilina, Antwerp, 1557), in whose dedicatory preface he declares that his purpose has been to enlighten the ignorant vulgar:

No dexaré, mientras tuviere ocio, de dar luz al vulgo imperito y sacarle de las tinieblas de la ignorancia, dándole muchos autores graves, ansí griegos como latinos, trasladados en su vulgar español, de cuyas muy claras fuentes pueda beber hasta hartarse, no solamente filosofía y medicina, pero también retórica. ${ }^{24}$

This was of course a claim that can be frequently found in many prefaces to translations, all over Europe - not all translators, however, defended clarity of style and rhetorically effective prose: to this effect, witness the fifteenth-century controversy between Alonso de Cartagena and Leonardo Bruni on account of the different ways in which Aristotle should be translated. But the question of the popularization of knowledge in Laguna's Dioscorides goes hand in hand with his philological method, and with a critical approach to its original contents-which are calibrated by Laguna's empirical experience obtained through his own botanic expeditions and his hands-on medical practice (as he declares, for instance, in his dedicatory epistle to Philip II in the 1555 edition, fols. $2 \mathrm{v}-3 \mathrm{r}$ ). One of the textual sources used by Laguna for his Spanish translation of the Dioscorides was Jean de la Ruelle's Latin translation from the original Greek, which had been printed in Alcalá de Henares in 1518 under the editorial supervision of none other than Elio Antonio de Nebrija. There was a well-established medieval tradition of comprehensive medical compendia and summae, but as his own testimony demonstrates the new elements in Laguna's endeavour consist in his emphasis on the distribution of this knowledge among a wider readership after the original texts have been properly recovered and cleansed through the editorial strategies of humanist philology. These texts are then made available in clear and correct translations that feature a carefully elaborated critical apparatus, so that readers can exercise critical judgment and form their own opinion by choosing from amongst different possible interpretations. Laguna pursues, as he also tries to educate, a critical reader:

La orden que tuuimos de fabricar la presente obra, ò Amigo Lector, fue la siguiente. Primeramente procuramos de buscar todos los Codices Griegos de Dioscorides, ansi estampados, como escriptos de mano, y antiquissimos, que pudimos hallar en Italia: y después de hauerlos conferido y encontrado vnos con otros, hezimos la translation,

\footnotetext{
${ }^{22}$ P.L. Carver, ed. The Comedy of Acolastus. Translated from the Latin of Fullonius by John Palsgrave. London: Early English Text Society, 1937, p. 8.

${ }^{23}$ Those fyue questions, which Marke Tullye Cicero, disputed in his manor of Tusculanum: written afterwardes by him, in as manye bookes, to his frende, and familiar Brutus, in the Latine tounge. And nowe, oute of the same translated, \& englished, by Iohn Dolman, studente and felowe of the Inner Temple. London: Thomas Marshe, 1561. STC (2nd ed.) 5317

24 "I will not fail, as long as I can find the time, to enlighten the uneducated vulgar, and bring them out of the obscure mist of ignorance, providing many grave authors, Greek as well as Latin, translated into their vulgar Spanish, from whose clear springs they can drink to satiety, not just philosophy and medicine, but rhetoric too". Quoted in A. Prieto, "La extension democrática del Dioscórides" in García Hourcade \& Moreno Yuste, 2001, pp. 41-50, p. 50).
} 
siguiendo los mas fieles y verdaderos de todos ellos: y annotando juntamente en los márgenes, los mesmos lugares Griegos, à do quiera que conuenia discrepar de los otros interpretes: para que pudiesse cada vno sobre la tal discrepantia ser juez. ${ }^{25}$

His Gallenic texts, together with his Dioscorides, are Laguna's major claim to fame and popularity in the 16th and 17th centuries, and even beyond. His Dioscorides was by far Laguna's most successful work: it went through several editions in Salamanca $(1563,1566$, 1570, 1584, 1586), Valencia (1635, 1636, 1651, 1695), Barcelona (1677), and Madrid (1733, 1752, 1773 and 1783). Laguna also has his own entry in the third volume of N.F.J. Eloy's Dictionaire Historique de la Médecine Ancienne et Moderne (Mons, 1778, p. 2), where his activities are praised in the following terms: 'Ce médecin étoit bon critique, ainsi que le prouvent les corrections \& les commentaires qu'il a faits sur Dioscoride, sur divers endroits d'Hippocrate, d'Aristote, de Galien, \& c.' ['This physician was a good critic, as proved by the corrections and commentaries he produced on Dioscorides, and on diverse passages by Hippocrates, Aristotle, Galen, etc.']". Laguna thus joined the long list of doctors who applied the principles of philological humanism to the distribution of ancient Greek medical expertise. One of these early modern physicians was Miguel Servet, also known as Servetus. Both he and Laguna shared the same printer, Guilielmus Rovillius, a member of one of those great dynasties of early modern European printers that constituted the human and logistical infrastructure for the material production and distribution of knowledge. Rovillius was married to Margarita de Portonariis, who in turn was related to the Portonariis of Salamanca-printers of, inter alia, the work of the poet, scholar and translator Luis de León, or Gonzalo Pérez's Ulyxea. Servetus also worked as proof reader for the Frellon brothers and his activities included the composition and translation of grammar books from Latin into Spanish. ${ }^{26}$

Laguna also sought to capture the attention of his readers by combining scientific discourse with frequent digressions in a much lighter mode. Laguna's copious scholia abound with snippets couched in a variety of styles and contents that range from technicisms to amusing narrative resources pertaining to the uses of popular prose fiction, even folklore. In Laguna's translation of the pseudo-Aristotelian De virtutibus the proportion of commentary far surpases the extension of the translated text with anecdotes, jokes and autobiographical episodes (such as his visit to London). The agenda that underlies Laguna's deliberately varied style stems from the tragicomic combination of the serious with the humorous (both in style, and in content), in the spirit of the etymological meaning of the Latin concept of satura as a dish of mixed ingredients. Quintillian had already pontificated on De risu in his Institutio oratoria (VI.iii), and Petrarch himself had dealt with it in book II of his Rerum memorandum libri. Giovanni Pontano's 1502 De sermone (I.xii, "De urbanis et facetis") recommended a combination of urbanitas with iocunditas as the summum of civic refinement for the enlightened man of affairs. All these precedents sanctioned the legitimate use of satire and humour in combination with perfectly serious matter. Laguna thus followed a well-established tradition that gave him leave to indulge in what must have also been a personal inclination, combining the conversational style that stems from the ideal of writing as we speak-defended by Juan de Valdés in his Diálogo de la lengua - with Castiglione's warning against speaking "always in grave matters". Il cortegiano recommended the use "of amusing things, of games, jests and waggery, according to the occasion". And when speaking about "obscure or difficult" subjects, the courtier must "explain

\footnotetext{
${ }^{25}$ Appendix to Dioscórides ("Al benigno lector", numbered apart from the rest of the volume, fol. Iiii ") "The method we used in the composition of the present work, friendly reader, was as follows. First we sought all the Greek codices by Dioscorides, in both print and manuscript, and also the most ancient among them, that we could possibly find in Italy; after careful scrutiny and comparison with one another, we did the translation, following those among them that were most reliable and authentic, annotating on the margins those places in the original Greek where it was deemed fit to disagree from other translators: so that each of you could be the judge of these disagreements."

${ }^{26}$ For the connections between Servet and Laguna (who shared inter alia a common converso background), and their respective involvement in linguistic and editorial activities, see González Echeverría \& Ancín Chandía ("Andrés Laguna y Miguel Servet: Dos Médicos Conversos Humanistas del Siglo XVI", in García Hourcade \& Moreno Yuste, 2001, pp. 377-389) in particular pp. 376386 , where they claim to have found three grammars in whose composition Servetus was involved. These new findings also relate Servetus with the editorial activities of Mathurin Cordier.
} 
his meaning with precision of both word and thought, and make every ambiguity clear and plain with a certain touch of unpedantic care". ${ }^{27}$

In the preface to his commentaries on Dioscorides Laguna had already adapted the satirical strategies of Lucian's Icaromennipus for his critique of incompetent doctors. And we can find one of the most amusing examples of Laguna's recourse to facetiae in his entry "De las Cantharidas, Buprestes, y Orugas de Pino", (II.liv, p. 155). After providing the translation from the Greek text, Laguna complements the original with his own empirical evidence. He describes the colour, shape and origin of these insects, and adds some other of their properties, one of which is that, when two or three of them are mixed with wine, they "provocan bravamente la orina, e incitan a la virtud genital", i.e. they provoke a strong emission of urine and incite to genital virtue. At this point Laguna cannot resist the urge to tell his readers the following story:

En cierta botica de Mets, residiendo yo en aquella ciudad, fue ordenada una medicina que llevava cantharidas, para cierto novio impotente, y juntamente otra de cañafistola para refrescar el hígado, y los riñones del Guardian de la Orden de San Francisco, febricitante: y aconteció que trastocándose los brevajes por yerro, el novio (el qual bebio la del Frayle) pusiesse aquella noche, del lodo, y aun peor la cama y la novia; y el Frayle por otra parte, que tomó la del novio, anduviesse por todo el convento, como podeis bien pensar hecho un endemoniado, que no bastavan pozos ni aljibes para le resfriar. ${ }^{28}$

Laguna also sprinkled his commentaries with fragments translated from other texts, and so Laguna's own translation of a few lines from Virgil (Georgics, IV.271-78) features in the entry on the Aster Atticus in the Dioscorides. (IV.cxxi, p. 452). In a very interesting case of intralinguistic translation Laguna also parodied the estrofa de pie quebrado, a type of stanza which for an early sixteenth-century Spanish reader evoked Jorge Manrique's late medieval elegy Coplas a la muerte de su padre. Laguna translated this solemn poetic pattern into an ironically damning description of the vine, which is so feracious and climbs with such vigour that it hides the sight of the lady from the eager eyes of a Petrarchist lover. Laguna uses this story to illustrate the properties of this plant, and claims that he does so "para recrear un poco al lector, cansado por ventura de la passada historia" (to entertain the reader, who may perchance be exhausted after the preceding passages). The paragraph that introduces the poem constitutes an excellent example of Laguna's technique of smooth transition from a scientific description of the physical features of the vine towards the type of discourse one would expect to find in more literary texts:

Pero es la vid tan ambiciosa, entonada y altiva, que se nos sube a las nuves de suerte que se hacen chapiteles con ella, y se cubren las ventanas, y açoteas de las muy altas torres, lo qual hace renegar muchas veces a los aflictos amantes, como renegava un galan enamorado, que yo conozco, a cuya instancia hicimos cierta invectiva contra una parra, que le había cubierto la galería por do solia su señora ordinariamente mostrarse, de la qual recitaré aquí algunos versos que se me acuerdan, para recrear un poco al lector, cansado por ventura de la passada historia

Parra por mi mal nacida

Que ansi me tienes mi amor.

Eclipsado.

\footnotetext{
${ }^{27}$ Castiglione, Book of the Courtier, trans. L.E. Opdycke, Hertfordshire: Wordsworth, 2000, I.34, pp. 45-6

28 "In a certain pharmacy in Metz, when I lived in that city, an order was placed for a medicament that contained cantharides, by certain impotent bridegroom, and together with this one, another order was placed for a formula with Cassia fistula [i.e. Golden Shower Cassia, or Golden Shower Tree, whose root is used as a potent purgative], to refresh the liver and kidneys of the Guardian of the Order of Saint Francis, who was suffering from a fever; and it came to pass that the beverages got mixed up by mistake, and the bridegroom (who drank the potion meant for the friar) covered the bed, and the bride, with mud, and much worse; on the other hand, the friar, who took the beverage prepared for the bridegroom, wandered frantically about the convent all night long, as you may well imagine, as if he were possessed by the devil, never finding enough wells or fresh water reservoirs to cool him down."
} 


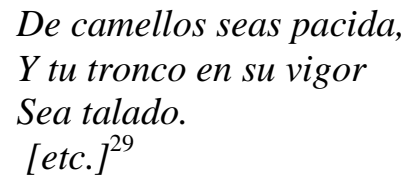

Laguna managed to create a colloquially varied register for his satural contents, which are peppered with humorous stories, entertaining parodies, and historical or autobiographical episodes with news from abroad - such as his description of the cockfights in London, and his encounter with Wyatt - to popularize matters that originally belonged in early modern scientific discourse. He justified his use of plain style, which was deliberately devoid of the eloquence displayed by other authors, because: "I have spent most of my life away from the Hispanic kingdoms, and with my current endeavour I have sought not to adorn my expression, but to explain with great fidelity and much clarity the great mysteries of Nature". 30

Other contemporary author who indulged in this sort of popularizing encyclopedism was Pedro Mexía, whose Silva de varia lección (Seville, 1540) was translated into Italian by Mambrino Roseo de Fabriano (Venice, 1544), into French by Claude Gruget from Mambrino's Italian version (Les Diverses leçons de Pierre Messie, Paris, 1552), and finally from its French version into English by Thomas Fortescue. According to figures provided by Dominique de Courcelles there are 32 Castilian editions and at least 75 different translated editions (among them 30 editions in Italian, 31 in French, 5 in English, 5 in Dutch, and 4 in German) of Mexía's Silva. In his preface, Mexía declared that his purpose was to distribute among readers in the vernacular the sort of knowledge which so far had only been available to those who could read Latin. ${ }^{31}$ If the international dimension of Mexía is attested by its numerous European translations, the transnational readership that Laguna pursues with his Dioscórides is proved by his address "Al benigno lector". To facilitate the communication of his contents to other nations, he claims, Laguna has included after each entry translations of the names of the plants and animals into as many as nine different languages, and he has also illustrated those entries "de aquellas plantas que suelen encontrarse en la Europa" to facilitate the identification of these common European plants (1555, fol. Iiii $\left.{ }^{\mathrm{V}}\right)$. His appearance in Don Quijote (chapter $18,1^{\text {st }}$ part) attests to Laguna's success as a popularizer of scientific knowledge. His work was known to a considerable diversity of readers, which proves that he managed to appeal to an audience beyond the specialized readership of humanist doctors. His entertainingly mixed style and comments must have undoubtedly contributed to this.

Laguna's target was a new type of enlightened reading community acquainted with the latest developments in a variety of disciplines. This audience - of which Laguna himself was a member - had access to this common knowledge from an increasing variety of authors and disciplines through the mediation of works like Ravisius Textor's Officina (Paris, 1520) or Erasmus' Adagia. All this is of a piece with the increasing encyclopedism facilitated by print and the weaving of a European network of common translational and transnational knowledge. Humanist compilations, miscellanies, adagia, and other handbooks for composition constituted

\footnotetext{
${ }^{29}$ Pedacio Dioscórides Anazarbeo, 1555, V.i, "De la vid", pp. 502-505. "The vine is so ambitious, spirited and haughty, that it does climb up to the clouds, so that capitals are decorated with it, windows and terraces in very high towers are covered with it, which frequently grieves poor dejected lovers, as one gallant lover of my acquaintance did grieve, at whose behest we composed an invective against a vine that had covered a gallery where his lady used to appear frequently, of which invective I shall rehearse here some lines that I can now remember, to entertain the reader, who may perchance be exhausted after the preceding passages: Oh thou ill-begotten vine / that doth thus eclipse / my love. / May you be grazed of camels / and in all its vigour / your stem be hacked". The poem goes on in a similar mock-Petrarchist tone for several stanzas.

30 “... aunque nuestro estilo no sea tan elegante y casto, como el de algunos escriptores de nuestros tiempos, que hazen profession d'eloquentes, no por esso deue nadie marauillarse: visto que hemos gastado la mayor parte de nuestra edad fuera de los reinos de España y procurado, en el presente negocio, no tanto de adornar la oración como de explicar muy fielmente y con gran claridad los misterios de la Naturaleza". This appears in one of the appendixes to the 1555 Dioscorides (numbered apart from the rest of the volume), fol. Iiii2 $2^{\mathrm{r}}$.

${ }^{31}$ Pedro Mexía. Silva de Varia Lección. Ed. Isaías Lerner, Madrid: Castalia, 2003, pp. 39-41. For the figures, see Dominique de Courcelles's "La mélange des savoirs: pour la connaisance du monde et la connaissance de soi au milieu du XVI siècle dans la Silva de varia lección du Sévillan Pedro Mexía”, in Dominique de Courcelles, ed. Ouvrages Miscelanées \& Théories de la Connaissance à la Renaissance, Paris \& Geneve: Champion \& Droz, 2003, pp. 103-116, p. 104.
} 
Laguna's sources. His defence of clarity, accuracy and the middle style turns him into an epitome of the average enlightened European citizen-humanist - a large class of educated readers, compilators, and translators, a step below as it were the great names of Erasmus or Vives. Laguna sought to entertain the non-specialized audience of curiosos lectores as he also made available his text for the class of middling professionals-such as midwives, or physicians - whose knowledge of Greek, Latin, or advanced scientific skills were either defective or nonexistent. In a way the stylistic variety and the combination of scientific matter with jokes, autobiographical snippets, and personal opinions on political, social, cultural and religious matters prefigures the discursive diversity that constitutes the texture of Cervantes's Don Quijote, Mateo Aleman's Guzmán de Alfarache, and of certain other varieties of early modern prose fiction. This taste for commentary, digression and the tragicomic satura of serious and humorous matter appears at the founding moment of the early modern novel and was elevated to an ironically sophisticated form of art in followers of Cervantes like Lawrence Sterne. It was also of a piece with common habits in early modern translation, which frequently added disproportionate copia to the rendering of the source text before more strict principles of fidelity to the original were established. See for instance the cases of Francisco de Encinas's translations of Lucian (Diálogos de Luciano, no menos ingeniosos que provechosos, Strassbourg, 1550), Pedro Sánchez de Viana's translation of Ovid (Las transformaciones de Ouidio, Valladolid, 1589), or Francisco López de Villalobos's translation of Plautus's Anphitryon (Alcalá de Henares, 1517).

Doctor Sánchez de Viana's commentaries-for he was also a physician-to Ovid's Metamorphoses display his sophisticated erudition, and reveal him as a poetically proficient scholar who was also conversant in classical and contemporary literary theory. His lengthy introduction to Las transformaciones bears a most interesting - and still unexploredcomparison with neo-Latin poetics, with Italian treatises on the same topic, and with Sidney's Defence of Poesy ${ }^{32}$. Villalobos's Plautus stands in sharp contrast with Viana's Ovid, and is closer to Laguna in several important respects. His Anphitryon saw print for the first time in an anonymous edition in 1517. In 1543, however, and in several subsequent editions that prove a certain degree of popularity $(1544,1570,1574$ and 1583) it did appear as part of a volume titled Los problemas de Villalobos: que tracta de cuerpos naturales y morales, y dos dialogos de medicina: y el tratado de las tres grandes y una cancion y la comedia de Amphitrion (Zamora, 1543). The unwieldy title gives away the satural nature of the volume: Los problemas features Villalobos's Plautus (with comments), moral treatises combined with scientific essays, dialogues interspersed with comic stories in prose peppered with jokes on enemas and bodily gases, and passages that verge on the picaresque. He shares with Laguna his explicit endorsement of a clear style that aims to communicate contents effectively rather than show off the erudition of the author. One of his prose pieces features a reported dialogue in which Villalobos's voice stands as the narrator's. Here Reason argues with Wrath, Envy, Pride, and Avarice in defence of peace. Reason uses the conflicts between Francis I and Charles V to illustrate, inter alia, the iniquities of war and the pernicious effects of bad counsellors. Villalobos sides with the Imperial party, as Laguna did in his Europa oration-delivered, and published in 1543, the same year in which the first edition of Los problemas was issued in Zamora. Like Laguna, Villalobos defends a negotiated via media to end these conflicts. Los problemas de Villalobos also features veiled references to the harassment he arguably underwent as a result of its author's Jewish converso background. These troubles must have intensified after the death of Empress Isabel in 1539, when Villalobos's protegé and fellow converso physician, Andrés Laguna, decided to put some distance between himself and the court, and departed for London. Depressed and longing for a liberating death, Villalobos ends his Problemas with an epistle dated on October 6th 1540, in which he declares his intention to

\footnotetext{
32 On Viana, see Marcelino Menéndez Pelayo, "Sánchez de Viana, Pedro" in Biblioteca de Traductores Españoles, 4 vols. Santander: CSIC / Aldus, 1953, vol IV, pp. 233-243. The only modern edition is Las Metamorfosis de Ovidio, edited, with an introduction, by J.F. Alcina (Barcelona: Planeta, 1990).
} 
abandon the Imperial court for good. ${ }^{33}$ Laguna and Villalobos, good-humoured as their prose may have been, had also personally experienced more obscure episodes that undoubtedly contributed to inspire their defence of peace and tolerance.

Literary, scholarly, and scientific translation intersect with the normative ideal of clear prose in a proper and elegant middle style as part of a larger endeavour to educate these new reading communities. These concerns also overlap with the international network of European scholars and their half-idealistic, half-self-interested proposals for the peaceful and harmonious development of Europe as a cultural and political community at a time when the continent was torn apart by internal dissension and under threat from foreign powers. Laguna is just one among this school of humanists, courtiers, scholars, and translators who sought to find a middle ground where disputing European factions could reunite to regain what they construed as a lost unity and common sense of purpose. As they did so, they also attempted to take stock of the proliferating cultural others: the Turkish Empire, the peoples of the Americas or other regions that extended as far as China. In examining the doctrinal pros and cons of different theological, cultural and political positions as part of their endeavour to recover the science and the knowledge of Classical Antiquity, in their efforts to compile and disseminate the treasures of past scientists and scholars, and in translating them first into Latin, and then into the different vernaculars, Laguna and his peers stitched together an incipient notion of early modern Europe. In their attempt to emphasise what brought all the warring factions together, many of them came up with an early modern version of the concept of tolerance. Starting with Erasmian proposals for a creed that focused on the adiaphoric heart of Christian doctrine, and spurred by the news brought home by explorers, merchants and missionaries all around the Globe, the subsequent generations went beyond Christianity and elaborated a universal religion which in some cases absorbed not just Islam and Judaism but also other non-European belief systems into a wider world-view. The picture they painted was neither whole nor self-sufficient - it rather emerged as a patchwork of proposals that constituted a network of tensions engaged with each other in an inherently unstable dialectical framework. But in doing so they prefigured some of the subsequent developments of Enlightened Europe. Diplomats, travelers, exiled scholars, publishers and translators were there to facilitiate the whole process.

\footnotetext{
${ }^{33}$ On Villalobos see Beth S. Tremallo. "El Anfitrión de Francisco López de Villalobos” (Anuario de Letras, 27(1989): 313-328), and her Irony and Self-Knowledge in Francisco López de Villalobos (New York \& London: Garland, 1991); also L.S. Granjel, Vida y obra de López de Villalobos (Salamanca: Trabajos de la Cátedra de Historia de la Medicina, 1979). There is a recent facsimile of Los problemas, which reproduces the Zaragoza edition of 1544, published in two volumes for Pfizer and the Biblioteca de la Real Academia Nacional de Medicina by Lunwerg (Barcelona \& Madrid, 2004).
} 